\title{
Letter to the Editor of European Archives of Otorhinolaryngology about a paper "Classification of parotidectomies: a proposal of the European Salivary Gland Society" by Quer et al.
}

\author{
Małgorzata Wierzbicka ${ }^{1}$
}

Received: 16 March 2016/Accepted: 23 March 2016/Published online: 6 April 2016

(c) The Author(s) 2016. This article is published with open access at Springerlink.com

\section{Dear Editor,}

A paper "Classification of parotidectomies: a proposal of the European Salivary Gland Society" by M. Quer et al. recently published in this journal provides comprehensive classification of the parotidectomy.

The first note worthy contribution unifies the surgical anatomy of the parotid region. Although during the embryogenesis the parenchyma is evolved as one indivisible whole anatomic. A surgical division of the parotid gland to two or three parts has been the practical norm. The relation between the parotid gland, facial nerve and the cover plans suggest bilobular architecture or three "lobes" in relation to facial nerve main branches. The ESGS proposes to accept and use the Barcelona classification with one modification. Finally the division of the parotid gland into five levels has been adopted by ESGS to report the surgery performed.

The key issue that was approved was the classification system for parotid surgery, which uses two basic terms to define the procedures: extracapsular dissection and parotidectomy. In all descriptions of the operation the number levels and nonparotid structures are specified.

The simple, clear and comprehensive classification is especially valuable for centers, that lead registration. In our institution the Poland National Registry of Benign Parotid

This comment refers to the article available at doi:10.1007/s00405-016-3916-6.

Małgorzata Wierzbicka

maria.mucha@gmail.com; otosk2@ump.edu.pl

1 Department of Otolaryngology and Laryngological Oncology, University of Medical Sciences, Przybyszewskiego 39, 60-663 Poznan, Poland
Tumors has been conducted and a variety of techniques, along with certain dispersion in the criteria that define them, has led to some confusion about the surgery performed. Thus we are personally grateful for this new classification, that facilitates multicentre communication.

I would like to take this opportunity if I may to pose one question. The temporomandibular joint (TMJ) is in the immediate vicinity of the I and IV parotid levels $[1,2]$. This structure may require surgical violation or resection, not only when involved in primary tumours of the bone adjacent to the mandible, but in tumours derived from the parotic $[3,4]$. TMJ is also important in using joint structures as margins in tumour resection. In Table 5 nonparotic structures that could be removed are listed. I wonder if besides the mastoid bone and lateral temporal resection, additional TMJ should be included, although it could possibly be placed in category "others to be defined".

Open Access This article is distributed under the terms of the Creative Commons Attribution 4.0 International License (http://crea tivecommons.org/licenses/by/4.0/), which permits unrestricted use, distribution, and reproduction in any medium, provided you give appropriate credit to the original author(s) and the source, provide a link to the Creative Commons license, and indicate if changes were made.

\section{References}

1. Al-Jamali JM, Voss PJ, Bayazeed BA, Spanou A, Otten JE, Schmelzeisen R (2013) Malignant tumors could be misinterpreted as temporomandibular joint disorders. Oral Surg Oral Med Oral Pathol Oral Radiol 116(5):e362-e367

2. Miyamoto H, Matsuura H, Wilson DF, Goss AN (2000) Malignancy of the parotid gland with primary symptoms of a temporomandibular disorder. J Orofac Pain 14(2):140-146 
3. Klasser GD, Epstein JB, Utsman R, Yao M, Nguyen PH (2009) Parotid gland squamous cell carcinoma invading the temporomandibular joint. J Am Dent Assoc 140(8):992-999

4. Voss PJ, Leow AM, Schulze D, Metzger MC, Liebehenschel N, Schmelzeisen R (2009) Navigation-guided resection with immediate functional reconstruction for high-grade malignant parotid tumour at skull base. Int J Oral Maxillofac Surg 38(8):886-890 